\title{
The Characteristics of Arrogant Speeches Used by the Players in Tennis Court
}

\author{
Sigit Haryanto Djatmika ${ }^{1}$, Wakit Abdullah ${ }^{2}$, Dwi Purnanto ${ }^{3}$ \\ \{Sh288@ums.ac.id ${ }^{1}$, fib@mail.uns.ac.id $\left.{ }^{2}\right\}$ \\ ${ }^{1}$ Universitas Muhammadiyah Surakarta, Indonesia \\ ${ }^{2,3}$ Universitas Sebelas Maret, Indonesia
}

\begin{abstract}
Arrogant speeches are interesting to be investigated, especially viewed from their properties or characteristics. Arrogant speeches are part of expressive speech that cannot be separated from the human life. Arrogant speeches have a closed relation to the psychological state. The state of their feelings may take place at home, office, society and sport places. One of the sport places that often exists arrogant speeches is in tennis court. In this, arrogant speeches become the alternative utterances that uttered by the players. This qualitative research used active participant and observation in collecting the data. Then the data were analyzed by using Spradley method and descriptive method. And after being analyzed descriptively, the findings dealing with the characters found in arrogant speeches used by them are as follows: 1. Benefiting O1 (speakers), 2. Underestimating $\mathrm{O} 2$ (hearers), and 3. Using comparative utterance.
\end{abstract}

Keywords: arrogant speeches; expressive speech; tennis court; special characteristics

\section{Introduction}

When we say something to someone, at the same time we also do something dealing with the arrangement of meaningful words. Word constructions that we use in everyday communication are known as speech acts. People may produce whatever speeches wherever and whenever. One aspect of speech acts is expressive act. When people express their psychological state, their expressions simultaneously carry out certain acts (Tauchid: 2016). These acts are what so-called expressive speech acts. The following utterances are the examples of expressive speech acts; "wow", "excellent result!", "that was stupid", "he has damn well spent our money", etc (Tauchid: 2016). Other examples of expressive acts are Oh, I'm sorry, Fermine, Thank you!, I am so mad!, I love you, Hannah Montana (Handayani:2015). The examples given by both former researchers deal with texts. Texts produced, of course, depend on the context of situation and physiological mood of the producer. In an hour, speakers may utter (1) not only expressive but they also produce directive such as: bolane ganti sing anyar 'change the ball with the new one', (2) declarative: mainmu bagus 'your play is good', and (3) commisive: sing menang njajakke ya 'the winner treats us, ok', and Those italic speeches are among hundreds of texts resulted on the basis of the contexts, and in this case the context is the sport, specifically tennis court. Speech acts and tennis court are like a coin. They are not able to be separated. The players always use utterances when playing or taking a rest. So, there are many interested aspects of speeches that can be elaborated dealing with the language and the tennis community. 
The article focused on sport has been conducted by Milic (2013) with the title: The Influence of English on Serbian Sports Terminology. The findings indicated that the number of English borrowings could be lower than already stated if the creation of new terms was immediately followed by the process of standardization which, from the aspect of language contacts, is a matter of linguistics rather than sport. Second article was written by Haryanto (2018). He studied the relation between language and tennis court and gave the topic Humor dalam Olah Raga Tenis Informal: Referensi dan Fungsi in national seminar KBSP V. The points of the finding are: referring (name, place, situation, and trademark) and function (recreation, mocking, and direction). Two articles citied has motivated the writer conducted a study about language and sport, especially arrogant speech done by the tennis players. The study dealing with arrogant speech in tennis court, up to now, doesn't be conducted yet. So, this becomes the basic reason for the writer to do the research.

As stated in the title, this article wants to present to the reader about the characteristic of arrogant speeches. So it may be helpful if we know at a glance what is meant by character intended. Collin Dictionary stated that characteristic refers to the qualities or features that belong to them and make them recognizable. It has synonym to feature, mark, and property. Then, talking about arrogant speeches, we are better to refresh our memory about them. Arrogant in Indonesian means sombong and speech means perkataan atau omongan (Javanese). In Cambridge dictionary, it is explained that arrogant is unpleasantly proud and behaving as if you are more important than other people. The example is as follows: I watched the interview and thought he seemed quite arrogant. Arrogant is also explained by Allah. In Quran (Lukman: 18) it is said that: And do not turn your cheek (contempt) toward people and do not walk through the earth exultantly. Indeed, Allah does not like everyone selfdeluded and boastful. Arrogant is defined as an action dealing with stopping the truth and lookdown others (HR. Muslim no.91). Sa'id Hawwa (2006) defined arrogant is a big self attitude and consider the other trivial, feel himself more than other. Two explanations (characteristic and arrogant) lead the writer to find what the characteristics of arrogant speeches uttered by tennis players.

\section{Research Method}

This qualitative research was done at January - Mei 2019 in Kartasura, Sokoharjo, Jawa Tengah, Indonesia. The data were collected by using active participant and observation method. The form of the data were arrogant utterances. The data source was the tennis player utterances. The collected data were analyzed by Spradley: componential analysis and descriptive method. The results of data analysis were presented descriptively.

\section{Analysis and Discussing}

The twenty data were analyzed based on componential analisis and the results of analysis are as follows. The first result deals with the first characteristic of arrogant speeches found in the tennis court namely: benefit for $\mathrm{O} 1$ (speakers). There are eleven data showed this (see table 1). 
Table1. Benefit for O1 (speakers)

\begin{tabular}{|c|c|c|}
\hline no & utterances & meaning \\
\hline 1. & $\begin{array}{l}\text { Mainmu ora standar } \\
\text { 'your paly is not stadard' }\end{array}$ & Standard non standard \\
\hline 2. & $\begin{array}{l}\text { Pemain tidak berperingkat masuk disik } \\
\text { 'the unrank player play first' }\end{array}$ & Rank and unrank \\
\hline 3. & $\begin{array}{l}\text { Tak purpapat } \\
\text { 'I beat four' }\end{array}$ & Smart and not smart \\
\hline 4. & $\begin{array}{l}\text { Sing during jejeg main disik } \\
\text { 'that is not fine, play first' }\end{array}$ & Perfect and not perfect \\
\hline 5. & $\begin{array}{l}\text { Ora kiringeten main karokoe } \\
\text { 'not sweat paly with you' }\end{array}$ & Clever and not clever \\
\hline 6. & $\begin{array}{l}\text { Kalah karo limang watt bangeten } \\
\text { 'defeated with five watt is too embarresed' }\end{array}$ & Strong and not strong \\
\hline 7. & $\begin{array}{l}\text { Aku kalah karo kowe pilih ora main sesasi } \\
\text { 'If I am lost with you, I will not play in a month' } \\
\text { Aku main kok ora kringeten } \\
\text { 'I played but not get sweat' }\end{array}$ & Strong and not strong \\
\hline 8. & $\begin{array}{l}\text { Mainku mau lagi } 50 \% \\
\text { 'my play, just now, was only } 50 \% \text { ' }\end{array}$ & Clever and not clever \\
\hline 9. & $\begin{array}{l}\text { Musuh sing elek-elek sik dienggo pemanasan } \\
\text { 'play with the bed one first, for warming up' }\end{array}$ & Power and not power \\
\hline 10. & $\begin{array}{l}\text { Musuhku lagi ajaran } \\
\text { 'my oppenant was beginner' }\end{array}$ & Goodness and not goodness \\
\hline 11. & & Mature and not mature \\
\hline
\end{tabular}

Underestimate $\mathrm{O} 2$ also becomes the second characteristics of arrogant speeches done by the tennis players. There are eleven data showed it (see table 2).

Table 2. Underestimate O2 (hearers)

\begin{tabular}{lll}
\hline no & \multicolumn{1}{c}{ utterances } & \multicolumn{1}{c}{ meaning } \\
\hline 1. & $\begin{array}{l}\text { Kana main karo aku ethuk lima wis apik kuwi } \\
\text { 'you play with me and get five is good' }\end{array}$ & Lowering skills \\
2. & $\begin{array}{l}\text { Sik tak main karo adik-adik } \\
\text { wait, I will paly with the youngs' }\end{array}$ & Lowering experiences \\
\hline
\end{tabular}




\begin{tabular}{|c|c|c|}
\hline no & utterances & meaning \\
\hline 3. & $\begin{array}{l}\text { Pemain tidak berperingkat masuk disik } \\
\text { 'the unrank player play first' }\end{array}$ & Lowering rank \\
\hline 4. & $\begin{array}{l}\text { Kalah karo limang watt bangeten } \\
\text { 'defeated with five watt is too embarresed' }\end{array}$ & Lowering power \\
\hline 5. & $\begin{array}{l}\text { Pemain ecek-ecek wae main neng lapangan apik } \\
\text { 'bad player can not play in a good court' }\end{array}$ & Lowering rank \\
\hline 6. & $\begin{array}{l}\text { Aku kalah karo kowe pilih ora main sesasi } \\
\text { 'If I am lost with you, I will not play in a month' }\end{array}$ & Lowering smart \\
\hline 7. & $\begin{array}{l}\text { Wah mainmu mundak no, mundak lengkap, gandul, } \\
\text { out, mati dewe } \\
\text { 'heemm, your play increase, complete inreasing:net, } \\
\text { out, fault itself' }\end{array}$ & lowering consistency \\
\hline 8. & $\begin{array}{l}\text { Musuh sing elek-elek sik dienggo pemanasan } \\
\text { 'play with the bed one first, for warming up' }\end{array}$ & lowering skills \\
\hline 9. & $\begin{array}{l}\text { Apike nggonmu tambah wongsiji, dadi telu } \\
\text { ' it is better if your side was three' }\end{array}$ & lowering power \\
\hline 10. & $\begin{array}{l}\text { Pukulan cap pasar nongko } \\
\text { 'the sroke from pasar nongko' }\end{array}$ & lowering skills \\
\hline 11. & $\begin{array}{l}\text { Musuhku lagi ajaran } \\
\text { 'my oppenant was beginner' }\end{array}$ & lowering experiences \\
\hline
\end{tabular}

Comparative utterances also mark that the speeches belong to arrogant. There are four data showed it (see table 3).

Table 3. Comparative utterances

\begin{tabular}{|c|l|l|}
\hline no & \multicolumn{1}{|c|}{ utterances } & \multicolumn{1}{c|}{ meaning } \\
\hline 2. & $\begin{array}{l}\text { Mainmu mau wis apik, tapi aku luwih apik } \\
\text { 'your play was good, however my play was better' } \\
\text { 2. }\end{array}$ & $\begin{array}{l}\text { Musuh sing elek-elek sik dienggo pemanasan } \\
\text { 'play with the bed one first, for warming up' }\end{array}$ \\
3. & $\begin{array}{l}\text { Musuhku lagi ajaran } \\
\text { 'my oppenant was beginner' }\end{array}$ & I am more skillful than you \\
4. & $\begin{array}{l}\text { Lha ngeneiki kaya duren musuh timun } \\
\text { 'Wouu, it is like duren versus cucumber' }\end{array}$ & I am powerful than you \\
\hline
\end{tabular}




\section{Discussion}

The discussion is begun from Benefit for Ol (speakers). The players often said as: Mainmu ora standar 'your paly is not stadard'; Pemain tidak berperingkat masuk disik 'the unrank player play first'; Tak purpapat 'I beat four'; and so on. The meaning behind of those saying are talking about Standard non standard, Rank and unrank, Smart and not smart. O1 feels more standard, rank, and smart than O2. These speeches are suitable with Sa'id Hawwa (2006). He defined arrogant is a big self attitude and consider the other trivial, feel himself more than other. Here the $\mathrm{O} 1$ feels better than $\mathrm{O} 2$.

The second, underestimate $\mathrm{O} 2$ (hearers). The data indicated that all $\mathrm{O} 1$ utterances contain speeches that look down or underestimate O2. The examples are: Pemain tidak berperingkat masuk disik'the unrank player play first'; Tak purpapat' I beat four'; Sing during jejeg main disik 'that is not fine, play first'; Ora kiringeten main karo koe 'not sweat play with you'. Speeches as unrank player, not fine, and not sweat indicate O1 look down O2. These negative speeches are is in line with the statement said by Muslim as follows: Arrogant is defined as an action dealing with stopping the truth and look down others.

Comparative utterances such as: Mainmu mau wis apik, tapi aku luwih apik ${ }^{6}$ your play was good, however my play was better'; Siktak main karo adik-adik wait, I will play with the youngs'; Lha ngene iki kaya duren musuh timun 'Wouu, it is like duren versus cucumber'. The comparative speeches are shown with: your playing is good, but I am better; playing with the youngs; and duren versus cucumber'. These comparative utterances are part of arrogant speeches as stated by Sa'id Hawwa: arrogant is a big self attitude and consider the other trivial, feel himself more than other.

The three characteristics found in this study have relation to the research done by Haryanto and Milic. These findings add the scientific discussion about sport and language, kinds of speeches, and understanding the features of speeches. Of course, each speech has own characteristics.

\section{Conclusion}

Arrogant speeches are often found in real life. The people in society use it for many purposes. However, in general, the spirit of arrogant speeches is feeling better than others, though it is performed overtly or covertly. The tennis players are part of the society that uses arrogant speeches. Based on the result of the study in Kartasura tennis court, it is understood that some players use speeches that belong to arrogant. It can be traced from the speech characteristics as follows: 1. making benefit for himself, 2. underestimating the opponents, and 3. using comparative utterances. Those speeches performed by the players are suitable with the theories of arrogant speeches stated by Allah and mankind. Namely, speakers are always increasing benefit for himself, lowering hearers, and using comparative method.

\section{References}

[1] Handayani, Nur Vita. 2015. The Use of Expressive Speech Acts In Hannah Montana Session 1. Register. Vol. 8, No. 1, June 2015.

[2] Haryanto, Sigit. 2018. Humor dalam Olah Raga Tenis Informal: Referensi dan Fungsi in national seminar 
KBSP $V$ https://publikasiilmiah.ums.ac.id/xmlui/handle/11617/9901.

[3] Milic, Miler. 2013. The Influence of English on Serbian Sports Terminology in E.S.P. Today. Vol. 1. (1) 2013.

http://www.esptodayjournal.org/pdf/vol_1_1/4.\%20MIRA\%20MILIC\%20-\%20full\%20text.pdf

[4] Tauchid, Ahmad and Dwi Rukmini. 2016. THE PERFORMANCE OF EXPRESSIVE SPEECH ACTS AS

FOUND ON WAYNE ROONEY'S FACEBOOK. English Education Journal 6.1 2013.

file:///G:/Dwonloads/12772-Article\%20Text-25830-1-10-20160922.pdf

[5] Sa'ad Hawwa. 2006. Kajian Lengkap Penyucian Jiwa, Tazkiyatun Nafs, Intisari Ihya Ulumuddin. Jakarta: Pena PundiAksara. http://opac.perpusnas.go.id/DetailOpac.aspx?id=16144

[6] https://dictionary.cambridge.org/

[7] https://quran.com/31/18

[8] https://muslim.or.id/3536-jauhi-sikap-sombong.html

[9] Nordquist,Richard. 2019. Speech-Act Theory.

https://www.thoughtco.com/speech-act-theory-1691986

[10] https://www.collinsdictionary.com/dictionary/english/characteristic 